\title{
ALK Kinase Domain
}

National Cancer Institute

\section{Source}

National Cancer Institute. ALK Kinase Domain. NCI Thesaurus. Code C118902.

The intracellular portion of the ALK tyrosine kinase receptor protein that confers tyrosine kinase enzymatic activity. 